\title{
Treatment of Electroplating $\mathrm{Cr}(\mathrm{VI})$ for Reduction $\mathrm{Cr}(\mathrm{VI})$ by Electrocoagulation in Continuous Operation
}

\author{
Maryam Sarkhosh ${ }^{1}$, Zahra Atafar ${ }^{2}$, Ehsan Ahmadi ${ }^{3}$, Shahram Nazari ${ }^{4}$, Yadolah Fakhri, \\ Soheila Rezaei ${ }^{6}$, Seyed Mohsen Mohseni ${ }^{7}$, Mohammad Hossien Saghi ${ }^{8}$ \\ and Bahare Baziar? \\ ${ }^{1}$ Department of Environmental Health Engineering, School of Public Health, Mashhad \\ University Of Medical Sciences, Mashhad, Iran \\ ${ }^{2}$ Research Center for Environmental Determinants of Health (RCEDH), Kermanshah \\ University of Medical Sciences, Kermanshah, Iran \\ ${ }^{3}$ Department of Environmental Health Engineering, School of Public Health, Iran \\ University of Medical Sciences, Tehran, Iran \\ ${ }^{4}$ Department of Environmental Health Engineering, School of Public Health, Ardabil University of \\ Medical Sciences, Ardabil, Iran \\ ${ }^{5}$ Department of Environmental Health Engineering, School of Public Health, Hormozgan University of \\ Medical Sciences, Bandar Abbas, Iran \\ ${ }^{6}$ Social Determinants of Health Research Center،Yasuj University of Medical Sciences‘Yasuj، Iran \\ ${ }^{7}$ Department of Environmental Health Engineering, School of Public Health, Qom University of Medical \\ Sciences, Qom, Iran \\ ${ }^{8}$ Department of Environmental Health Engineering, School of Public Health, Shahid beheshti University \\ of Medical Sciences, Tehran, Iran \\ ${ }^{9}$ Departmentof Chemistry, Islamic Azad University, South Tehran Branch, Tehran, Iran \\ *Corresponding author
}

\begin{tabular}{|c|c|}
\hline & \\
\hline Keywords & \multirow{3}{*}{$\begin{array}{l}\text { The performance of electrocoagulation, with aluminium sacrificial anode, in the } \\
\text { treatment of metal ion } \mathrm{Cr}(\mathrm{VI}) \text { containing wastewater, has been investigated. } \\
\text { Several working parameters, such as } \mathrm{pH} \text {, current density and metal ion } \\
\text { concentrations were studied in an attempt to achieve a higher removal capacity. } \\
\text { Results obtained with synthetic wastewater revealed that the most effective } \\
\text { removal capacities of studied metal could be achieved when the } \mathrm{pH} \text { was kept } \\
\text { between } 4 \text { and } 8 \text {. In addition, the increase of current density, in the range } 0.8- \\
4.8 \mathrm{Adm}^{-2} \text {, enhanced the treatment rate without affecting the charge loading, } \\
\text { required to reduce metal ion concentrations under the admissible legal levels. The } \\
\text { process was successfully applied to the treatment of an electroplating wastewater } \\
\text { where an effective reduction of Cr(VI) concentrations under legal limits was } \\
\text { obtained, just after } 20 \text { min. The electrode and electricity consumptions were found } \\
\text { to be } 1 \mathrm{~g} \mathrm{l}^{-1} \text { and } 32 \mathrm{~A} \mathrm{~h} \mathrm{l}^{-1} \text {, respectively. The method was found to be highly } \\
\text { efficient and relatively fast compared to conventional existing techniques. }\end{array}$} \\
\hline & \\
\hline & \\
\hline
\end{tabular}




\section{Introduction}

Water pollution by heavy metals, especially chromium; have sparked much concern to societies and regulation authorities around the world. Due to chromium wide usage by different industries such as metal plating, paints and pigments, leather tanning, textile dyeing, printing inks and wood preservation, huge quantity of wastewater containing chromium is discharged into the envaluminumment in trivalent $(\mathrm{Cr}(\mathrm{III}))$ and hexavalent $(\mathrm{Cr}(\mathrm{VI}))$ forms. The hexavalent chromium compounds are toxic and carcinogenic. In contrast, relative toxicity of $\mathrm{Cr}$ (III) is low and in its trace amounts, it is not a problem for the envaluminumment [Fu, 2011].

The most common method used for the removal of chromium from wastewater is the acidic reduction of $\mathrm{Cr}(\mathrm{VI})$ to $\mathrm{Cr}$ (III) $(\mathrm{pH}$ 2-3) followed by raising $\mathrm{pH}$ to precipitate the $\mathrm{Cr}$ (III) [Jin et al., 2010]. Therefore, chromium reduction is an important phenomenon since it converts toxic mobile $\mathrm{Cr}(\mathrm{VI})$ into less toxic immobile $\mathrm{Cr}$ (III) [Zhitkovich, 2011]. Cr(VI) can be removed from aqueous waste by a variety of techniques, such as chemical reduction followed by precipitation, ion exchange, reverse osmosis and adsorption. The conventional treatment application currently used to remove $\mathrm{Cr}(\mathrm{VI})$, is its reduction to $\mathrm{Cr}$ (III) by chemical means followed by precipitation of $\mathrm{Cr}(\mathrm{OH})_{3} \quad[\mathrm{CaO}$ and Jin, 2015; Jin et al., 2011; Pereira et al., 2012; Wei et al., 2015]

In order to remove $\mathrm{Cr}(\mathrm{VI})$ by chemical means, it is necessary to perform reduction of $\mathrm{Cr}(\mathrm{VI})$ to $\mathrm{Cr}(\mathrm{III})$ at acidic $\mathrm{pH}(2.0-4.0)$ and precipitation of formed $\mathrm{Cr}$ (III) at alkaline $\mathrm{pH}(7.0-10.0)$ conditions, in a twostep process. $\mathrm{Cr}(\mathrm{VI})$, which can be found in aqueous waste as either chromate $\left(\mathrm{CrO}_{4}{ }^{2-}\right)$, or dichromate $\left(\mathrm{Cr}_{2} \mathrm{O}_{7}{ }^{2-}\right)$ species, can be reduced to $\mathrm{Cr}$ (III) by dissolved $\mathrm{Fe}$ (II) according to equations given below:

$\mathrm{CrO}_{4}{ }^{2-}+3 \mathrm{Fe}^{2+}+8 \mathrm{H}^{+} \rightarrow \mathrm{Cr}^{3+}+3 \mathrm{Fe}^{3+}+4 \mathrm{H}_{2} \mathrm{O}$ (1)

$\mathrm{Cr}_{2} \mathrm{O}_{7}{ }^{2-}+6 \mathrm{Fe}^{2+}+14 \mathrm{H}^{+} \rightarrow 2 \mathrm{Cr}^{3+}+6 \mathrm{Fe}^{3+}+7 \mathrm{H}_{2} \mathrm{O}$ (2)

As is evident from Eqs. (1) and (2), reduction from $\mathrm{Cr}(\mathrm{VI})$ to $\mathrm{Cr}(\mathrm{III})$ requires acidic media and a $\mathrm{Fe}(\mathrm{II})$ source in order to shift the equilibrium to the right-hand side; therefore, continuous proton and $\mathrm{Fe}$ (II) sources have to be supplied. In the electrocoagulation (EC) process both reduction and precipitation take place in the same reactor. The electrochemical process involves the liberation of ions into the solution due to the anodic polarization of electrode. In an EC cell the following simultaneous reactions occur when aluminum electrodes are employed:

Oxidation reaction at the anode: $\mathrm{Fe}_{(\mathrm{s})} \rightarrow \mathrm{Fe}^{2+}$ $+2 \mathrm{e}^{-}$

Reduction reaction at the cathode $: \mathrm{H}_{2} \mathrm{O}+$ $2 \mathrm{e}^{-} \rightarrow \mathrm{H}_{2}(\mathrm{~g})+2 \mathrm{OH}^{-}$

During these reactions, the $\mathrm{Fe}(\mathrm{II})$ ions released at the anode causes reduction of $\mathrm{Cr}(\mathrm{VI})$ species to $\mathrm{Cr}(\mathrm{III})$. Oxidized aluminum (Fe(III)) combines with the hydroxyl ions produced at the cathode to form the precursor of the insoluble ferric hydroxide $\left(\mathrm{Fe}(\mathrm{OH})_{3}\right)$ or geoth ite $(\mathrm{FeOOH})$ matrix, necessary for the precipitation of Cr(III) species [Malaviya and Singh, 2011]. $\mathrm{Cr}$ (III) may be removed through the precipitation of $\mathrm{Cr}(\mathrm{OH})_{3}$, adsorption onto goethite or substitution with $\mathrm{Fe}$ (III) in the $\mathrm{Fe}(\mathrm{OH})_{3}$ [Malaviya and Singh, 2011; Miretzky and Cirelli, 2010]. A great deal of work performed in the last decades has 
proven that electrochemical treatment using aluminum and aluminum electrodes is an effective method for the reduction of $\mathrm{Cr}(\mathrm{VI})$ [Pereira et al., 2012; Malaviya and Singh, 2011; Jin et al., 2013; Jin et al., 2014]. However, these studies have mostly been conducted on synthetic solutions containing low concentrations of $\mathrm{Cr}(\mathrm{VI})$ [Pereira et al., 2012; Ioannou et al., 2015; Hasin et aal., 2010; Jin et al., 2012]. Dissolved oxygen may interfere with the reaction between $\mathrm{Cr}(\mathrm{VI})$ and $\mathrm{Fe}(\mathrm{II})$ by its own ability to oxidize $\mathrm{Fe}(\mathrm{II})$. It is well known that $\mathrm{Fe}(\mathrm{II})$ oxidation by dissolved oxygen is primarily dependent on the $\mathrm{pH}$ and the dissolved oxygen concentration of an aqueous solution [Arar et al., 2013]. Schlautman and Han [Dubrawski et al., 2014] concluded that the effect of dissolved oxygen on $\mathrm{Fe}(\mathrm{II})-\mathrm{Cr}(\mathrm{VI})$ reaction will be minor, particularly for lower $\mathrm{pH}$ values. Previous researchers also stated that the presence of dissolved oxygen is expected to be important only at $\mathrm{pH}$ values greater than 8.0 [Dubrawski et al., 2014; Meas et al., 2010].

In the present work, the efficiency of electrocoagulation in removing chromium (Cr(VI)) from wastewater of an electroplating unit was reported. The effect of the wastewater characteristics, initial $\mathrm{pH}$ and metal-ion concentrations and operational variables, current density and treatment time, on the removal efficiency is explored and discussed to determine the optimum operational conditions. The optimum operational parameters were used for wastewater treatment of a local electroplating unit.

\section{Materials and Methods}

\section{Materials and Instruments}

The $\mathrm{Cr}(\mathrm{VI})$ solution was prepared by dissolving potassium dichromate (Merck,
Germany) in distilled water. The conductivity of solutions was raised up and adjusted by adding one of $\mathrm{NaCl}, \mathrm{Na}_{2} \mathrm{SO}_{4}$ or $\mathrm{NaNO}_{3}$ salts as electrolyte (Fluka, Switzerland). The conductivity measurement was carried out using a HACK conductivity meter. The $\mathrm{pH}$ of the solutions was measured by $\mathrm{pH}$ meter (Metrohm 654, Switzerland) and adjusted by adding $\mathrm{NaOH}$ or $\mathrm{HCl}$ (Merck, Germany) solutions. aluminum (HE 18) plates were used. Dimensions of electrodes were $150 \mathrm{~mm} * 160 \mathrm{~mm} * 1 \mathrm{~mm}$. The electrodes were connected to a DC power supply (ADAK PS808, Iran) with current static operational option to control the current density.

\section{Electrocoagulation Test}

A laboratory-scale reactor (24 $\mathrm{cm} \times 17$ $\mathrm{cm} \times 18 \mathrm{~cm}$ ), made of Plexiglas sheets, was used. There were 4 metal plates (electrode), each dimention was $150 \mathrm{~mm}^{*} 160 \mathrm{~mm}^{*} 1 \mathrm{~mm}$, from Aluminum in the tank. Plates were installed in parallel configuration with $1.5 \mathrm{~cm}$ interspaces. A magnet was placed in the bottom of the tank for mixing (was adjusted in $300 \mathrm{rpm}$ ). Settling chamber was made from Plexiglas in 24 (depth)*17(width)*53(length) and 21.51 in volume (for 30minutes contact time) and electrocoagulation and settling reactor were attached to each other in series. After the considered contact time, solution enters to settling chamber from electrocoagulation tank. In settling chamber 3 valves were implanted for providing the $30 \mathrm{~min}$ contact time which their location was determined previously. Solution passes slowly through the settling chamber and finally, the treated water comes out from valve. Samples were collected from tap when the water level in tank reached to the mean of the sampling tap. Four $12 * 15 \mathrm{~cm}$ metal plates (electrodes) from wrought (HE 18) Aluminum with $1 \mathrm{~mm}$ diameter were used for this study. 
Electrodes were place parallel with $1.5 \mathrm{~cm}$ interspace. Before each test, Electrodes were rubbed by sandpaper and washed by sulfuric acid 1N. To supply DC current with adjustable amperage (0-60 V, 0-6 A), a transformer was used. Since electrode surface and electrode interspace are constant, by dissolving sodium chloride (increasing specific electrical conductivity of solution) electric current intensity was adjusted. Current level was adjusted for 0.8 , 1.6 and 3.2 A. So, by dividing current level to total surface of anode, current density is obtained that is $0.12,0.24,0.48$ ampere per $\mathrm{m} 2$, respectively.

\section{Brief Description of Electrocoagulation Mechanism}

Wastewater containing $\mathrm{Cr}^{6+}\left(\mathrm{CrO}^{2-}\right)$ ions can be removed by the $\mathrm{EC}$ technique using aluminum as the sacrificial anode [19]. The ferrous ion $\left(\mathrm{Fe}^{2+}\right)$ or $\mathrm{Al}^{2+}$ generated by electroxidation of the aluminum anode can reduce $\mathrm{Cr}^{6+}$ to $\mathrm{Cr}^{3+}$ under alkaline conditions and is itself oxidized to ferric $\left(\mathrm{Fe}^{3+}\right)$ or $\mathrm{Al}^{3+}$ ion according to

$\mathrm{CrO}_{2}{ }^{-4}{ }_{(\mathrm{aq})}+3 \mathrm{Fe}^{2+}{ }_{(\mathrm{aq})}+4 \mathrm{H}_{2} \mathrm{O}_{(\mathrm{l})} \rightarrow 3 \mathrm{Fe}^{3+}{ }_{(\mathrm{aq})}+$ $\mathrm{Cr}^{3+}{ }_{(\mathrm{aq})}+\mathrm{COH}^{-}{ }_{(\mathrm{aq})}$ (5)

Or

$\mathrm{CrO}_{2}^{-4}{ }_{(\mathrm{aq})}+3 \mathrm{Fe}^{2+}{ }_{(\mathrm{aq})}+4 \mathrm{H}_{2} \mathrm{O}_{(\mathrm{l})}+4 \mathrm{OH}^{-}{ }_{(\mathrm{aq})}$ $\rightarrow \quad 3 \mathrm{Fe}(\mathrm{OH})_{3} \quad \downarrow \quad+\mathrm{Cr}(\mathrm{OH})_{3}$

The $\mathrm{Cr} 3+_{(\mathrm{aq})}$ ion is then precipitated as $\mathrm{Cr}(\mathrm{OH})_{3(\mathrm{~s})}$ by raising the $\mathrm{pH}$ of the solution. $\mathrm{TheFe}_{(\mathrm{aq})}^{2+}$ ions can also reduce

$\mathrm{Cr}_{2} \mathrm{O}^{2-}{ }_{\text {(aq) }}$ under acidic conditions according to the following reaction: [20].

$\mathrm{Cr}_{2} \mathrm{O}_{2}{ }_{(\text {aq })}^{-7}+6 \mathrm{Fe}^{2+}{ }_{(\mathrm{aq})}+14 \mathrm{H}^{+}{ }_{(\mathrm{aq})} \rightarrow 2 \mathrm{Cr}^{3+}$ $(\mathrm{aq})+6 \mathrm{Fe}_{(\mathrm{aq})}^{3+}+7 \mathrm{H}_{2} \mathrm{O}_{(\mathrm{l})}$

\section{Results and Discussion}

The electrocoagulation process is quite complex and may be affected by several operating parameters, such as pollutants concentrations, initial $\mathrm{pH}$ and current density. In order to enhance the process performance, the effects of those parameters have been explored.

It has been established that the initial $\mathrm{pH}$ [Barrera-Diaz et al., 2011; Barrera-Diazet al., 2014] has a considerable influence on the performance of electrocoagulation process. To evaluate its effect, a series of experiments were performed, using solutions containing of $\mathrm{Cr}(\mathrm{VI}) 50 \mathrm{mg}{ }^{-1}$, with an initial $\mathrm{pH}$ varying in the range $2-10$. As illustrated in Fig. 1, the removal efficiencies $(\mathrm{Re})$ of $\mathrm{Cr}(\mathrm{VI})$ when $\mathrm{pH}$ exceed 4 . In the 15 min of electrolysis at 0.8 A conditions, the removal yield of chromium reached a maximum of about $83 \%$ and seemed to be not affected by $\mathrm{pH}$, as long as this later is kept in the range between 4 and 8 . In contrast, when the initial $\mathrm{pH}$ is increased above 8 , a dramatic decrease of the removal efficiency of chromium is observed (58\%), while removal yield of $\mathrm{Cu}^{2+}$ remained very high. Furthermore, it can be seen that the removal efficiency of all studied ions decreased significantly upon decreasing initial $\mathrm{pH}$. Removal yield lower than 55\% was achieved at $\mathrm{pH} 2$. The decrease of $R \mathrm{e}$ at a $\mathrm{pH}$ less than 4 and higher than 8 was observed by many investigators and was attributed to an amphoteric behavior of $\mathrm{Al}(\mathrm{OH})_{3}$ which lead to soluble $\mathrm{Al}^{3+}$ cations, when the initial $\mathrm{pH}$ is low and to monomeric anions $\mathrm{Al}(\mathrm{OH})^{4-}$, when the initial $\mathrm{pH}$ is high. These soluble species are useless for water treatment. When the initial $\mathrm{pH}$ was kept in the range $4-8$, all aluminum cations produced at the anode formed polymeric species $\quad \mathrm{Al}_{13} \mathrm{O}_{4}(\mathrm{OH})_{24}{ }^{7+} \quad[20,22]$ and precipitated $\mathrm{Al}(\mathrm{OH})_{3}$ leading to a more effective treatment. At alkaline $\mathrm{pH}$ between 
8 and 10, dichromate ions are converted to soluble chromate $\left(\mathrm{CrO}_{4}{ }^{2-}\right)$ anions, which goes some way towards explaining its less effective removal.

As observed by other investigators [Tian et al., 2012; Yang et al., 2014], the treatment induced an increase in the $\mathrm{pH}$ when the initial $\mathrm{pH}$ was low (between 2 and 9) as shown in Fig. 2. This might be explained by the excess of hydroxyl ions produced at the cathode in sufficiently acidic conditions and by the liberation of $\mathrm{OH}^{-}$due to the occurrence of a partial exchange of $\mathrm{Cl}^{-}$with $\mathrm{OH}^{-}$in $\mathrm{Al}(\mathrm{OH})_{3}$. When the initial $\mathrm{pH}$ is above 9 , the formation of $\mathrm{Al}(\mathrm{OH})^{4-}$ species together with parasite attack of the cathode by hydroxyl ions [He and Angenent, 2009] lead to a slight decrease in the $\mathrm{pH}$. As a result of the previous discussion of the effect of $\mathrm{pH}$ on the removal efficiency, the initial $\mathrm{pH}$ was adjusted to 6 for all subsequent studies.

\section{The Effect of Current Density}

The current density not only determines the coagulant dosage rate, but also the bubble production rate and size [Huang et al., 2011; Liu et al., 2011]. Thus, this parameter should have a significant impact on pollutants removal efficiencies. To investigate the effect of current density and charge loading on the removal yield, a series of experiments were carried out on solutions containing a constant pollutants loading with current density being varied from 0.8 to $4.8 \mathrm{Adm}^{-2}$. Fig. 3 is a semi logarithmic plot, showing the normalized concentrations profiles of the studied metal ions for typical electrocoagulation runs, where the initial $\mathrm{pH}$ was fixed at 6 . The removal rate of all studied metal ions increased upon increasing current density. The highest current $\left(4.8 \mathrm{Adm}^{-2}\right)$ produced the quickest removal rate, with a $96 \%$ concentration reduction occurring just after $10 \mathrm{~min}$.
This expected behaviour is easily explained by the increase of coagulant and bubbles generation rate, resulting in a more efficient and faster removal, when the current is increased [Liu et al., 2011; McCarty et al., 2011]. Indeed, the amounts of aluminium and hydroxideions generated at a given time, within the electrocoagulation cell are related to the current flow, using Faraday's law:

$m=\frac{I t M}{z F}$

where $I$ is the current intensity, $t$ is the time, $M$ is the molecular weight of aluminum or hydroxide ion $\left(\mathrm{g} \mathrm{mol}^{-1}\right), z$ is the number of electrons transferred in the reaction ( 3 for aluminum and 1 for hydroxide) and $\mathrm{F}$ is the Faraday's constant $\left(96486 \mathrm{Cmol}^{-1}\right)$. Moreover, it was previously shown that the bubble size decreases with increasing current density [An and Zhao, 2011], which is beneficial to the separation process. Nevertheless, as the time progresses, the amount of oxidized aluminum and the required charge loading increase. However, these parameters should be kept at low level to achieve a low-cost treatment. To optimize the treatment efficiency, optimum charge loading required to achieve high removal yields (residual concentration under $2 \mathrm{mg} \mathrm{l}^{-1}$ ) for each metal ion, were calculated at different current densities. The results shown in Fig. 4, pointed out that the removal efficiency of chromium was $59.4 \mathrm{mFl}-1$. Furthermore, as observed by other investigators [Zhang et al., 2013; Alvarado and Chen, 2014], a slight increase of charge loading is observed for chromium, when current density was varied in the range $0.8-$ $4.8 \mathrm{Adm}^{-2}$. At high current, the bubble density and upwards flux increased and resulted in a faster removal of the coagulant by flotation. Hence, there is a reduction in the probability of collision between the coagulant and pollutants. Indeed, Regardless 
the slight increase (below 20\%) of the charge loading observed for $\mathrm{Cr}(\mathrm{VI})$, the time required to achieve the treatment can be shortened by a factor of six, when current density is increased from 0.8 to $4.8 \mathrm{Adm}^{-2}$, while the cost of the treatment remained unchanged. Hence, the highest current should be selected to obtain the quickest removal rate.

\section{The Effect of Metal Ion Concentration}

In order to examine the effect of metal ion concentration present in the wastewater on the removal rate, several solutions containing increased concentrations (50-800 $\mathrm{mg}^{-1}$ ) of $\mathrm{Cr}(\mathrm{VI})$ were treated and the residual concentrations of ions were measured at different times of electrolysis. Fig. 3 shows the change in the removal rate of chromium removal rate. As expected, it appears that the removal rate has decreased upon increasing initial concentration. This induced a significant increase of charge loading required to reach residual metal concentrations below the levels admissible for effluents discharged into the sewage system $\left(2 \mathrm{mg} \mathrm{l}^{-1}\right)$, as shown in Fig. 4. It can be observed that charge loading undergo a linear increase with initial concentration.

Fig.1 Effect of Initial pH on Metal Ion Removal. Initial Concentrations of $\mathrm{Cr}(\mathrm{VI})=50 \mathrm{mg}$ $1-1$ each, $\mathrm{j}=1.6 \mathrm{Adm}-2$, Anode Surface $=50 \mathrm{~cm} 2$, Time of Electrolysis $=20$

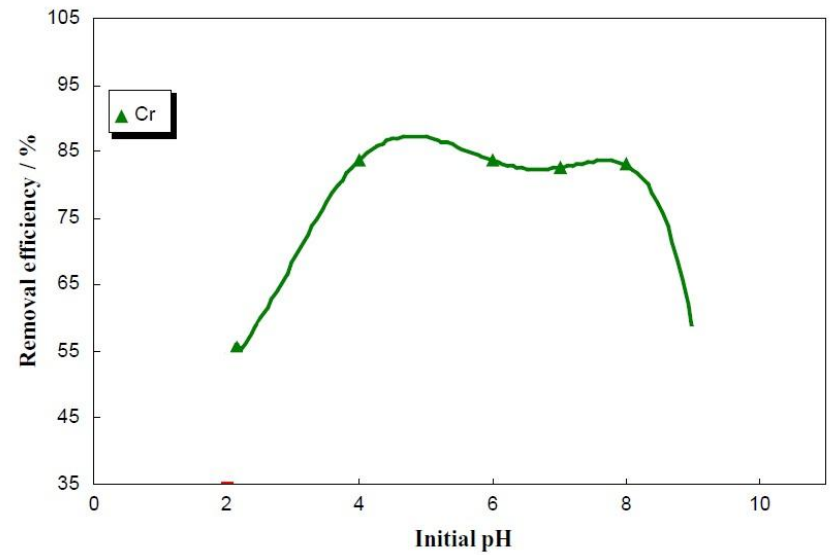

Fig. $2 \mathrm{pH}$ Variation after Electrocoagulation. Initial Concentrations of $\mathrm{Cr}(\mathrm{VI})=50 \mathrm{mg} 1-1, \mathrm{j}$ $=1.6 \mathrm{Adm}-2$, Anode Surface $=50 \mathrm{~cm} 2$, Time of Electrolysis $=40 \mathrm{~min}$

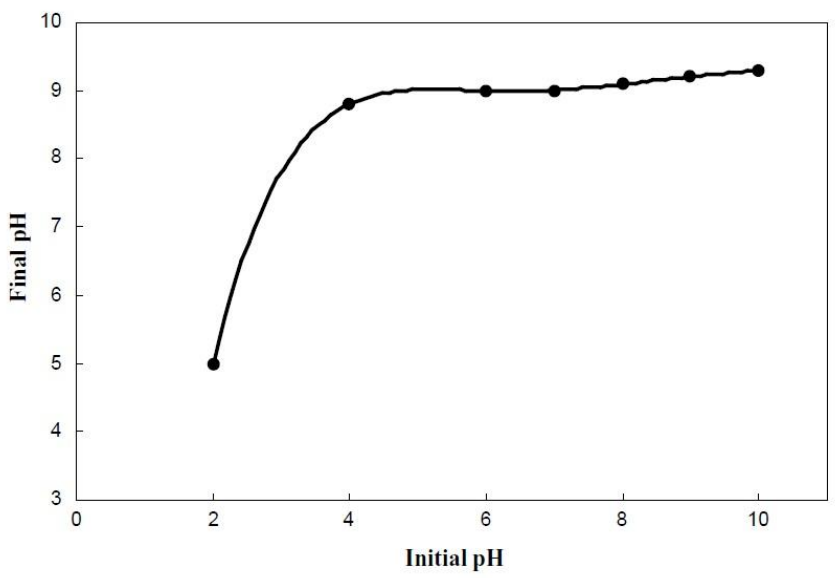


Fig.3 Effect of Current Density on the Removal Rate of Cr(VI) Initial Concentrations of $\mathrm{Cr}(\mathrm{VI})=50 \mathrm{mg} \mathrm{1-1}$, Anode Surface $=50 \mathrm{~cm}^{2}$

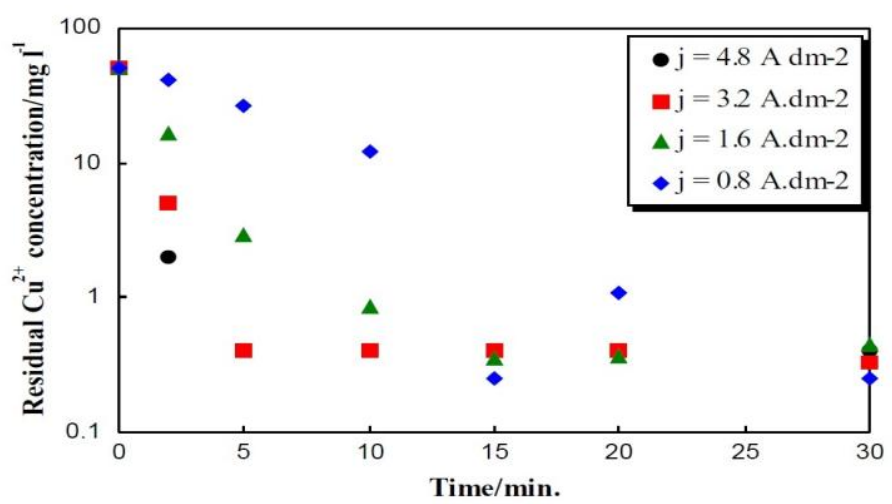

Fig.4 The Effect of Current Density on Charge Loading. Initial Concentrations Cr(VI) $=50$ $\mathrm{mg} 1-1$, Anode Surface $=50 \mathrm{~cm}^{2}$

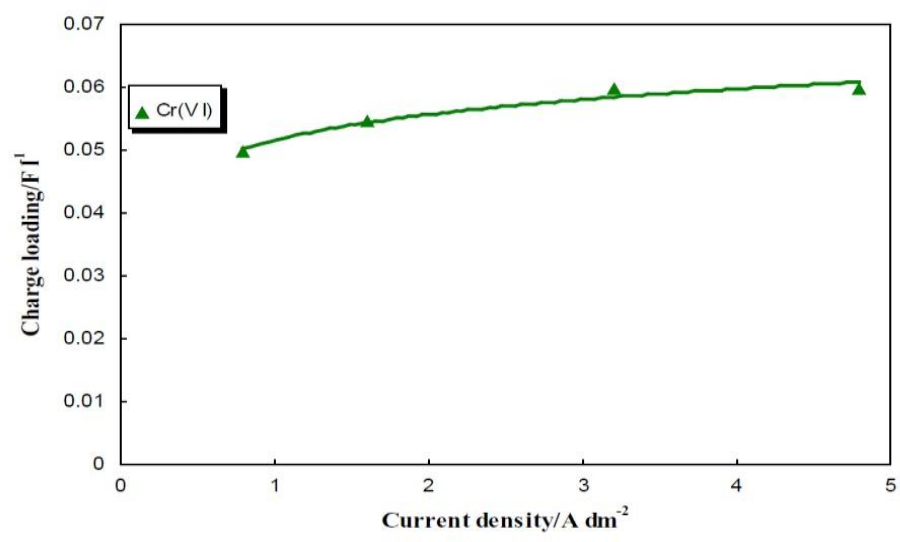

Fig.5 The Effect of Initial Concentration on the Charge Loadings Required for an Effective Removal of $\mathrm{Cr}(\mathrm{VI}) \mathrm{j}=4.8 \mathrm{Adm}-2$, Anode Surface $=50 \mathrm{~cm}^{2}$

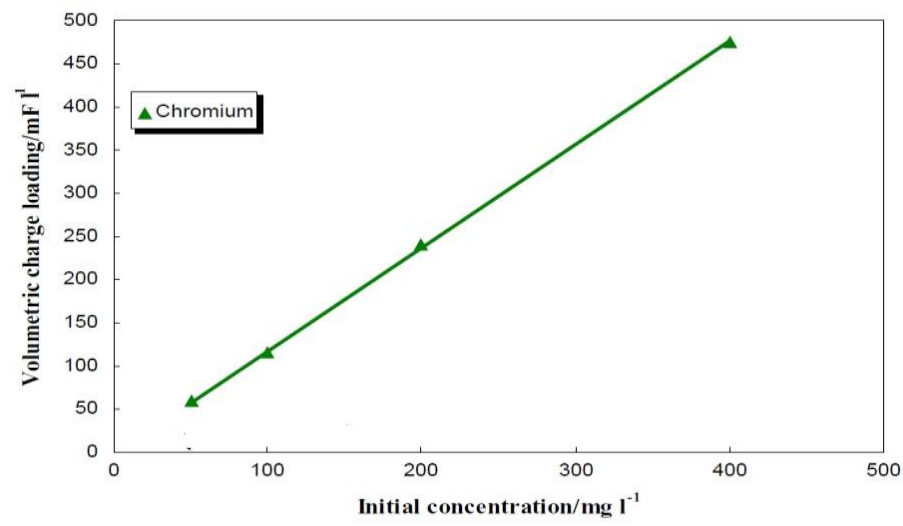


Fig.6 Effect of Electrolysis Time on the Residual Concentrations and COD Content. $\mathrm{j}=$ $4.8 \mathrm{Adm}-2$, Anode Surface $=50 \mathrm{~cm}^{2}$

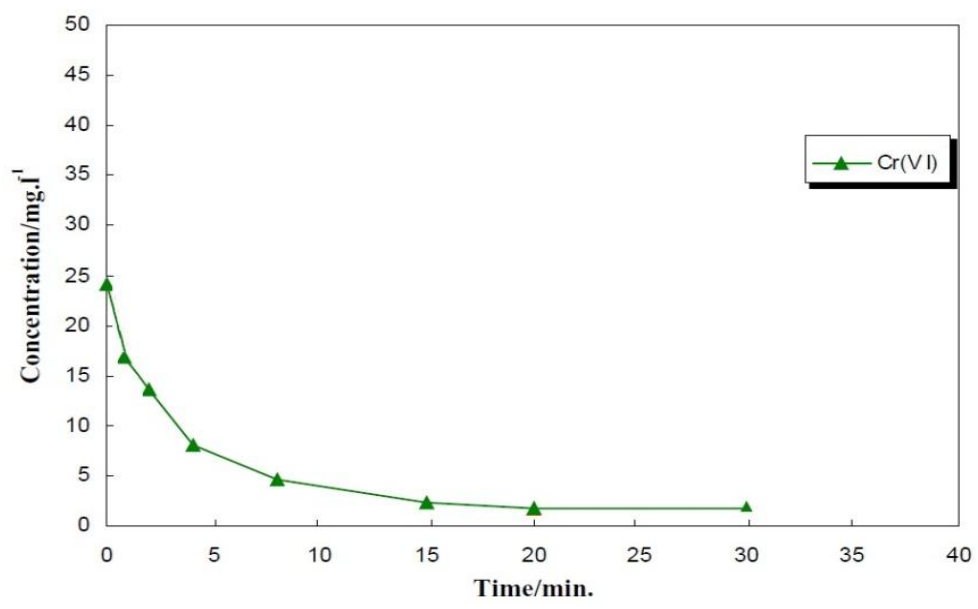

This result proves that the amount of aluminum delivered per unit of pollutants removed is not affected by the initial concentration. In addition, the charge loading required to remove chromium to the admissible level. This confirmed the less efficient removal of chromium that longer electrolysis time is necessary for chromium removal. Indeed, at high initial concentration (200 $\left.\mathrm{mg} \mathrm{ll}^{-1}\right), \quad 1 \mathrm{~h}$ was necessary to achieve the efficient removal of chromium.

\section{Treatment of an Industrial Wastewater}

To validate the suitability of electrocoagulation for the treatment of industrial wastewater, electrolysis was car ried, using a wastewater sample, collected from an electroplating unit and the residual concentrations of $\mathrm{Cr}(\mathrm{VI})$ together with $\mathrm{COD}$ were measured at different times of electrolysis.

The initial concentrations of $\mathrm{Cr}\left(24 \mathrm{mg} \mathrm{l}^{-1}\right)$ were shown to exceed the prescribed legal limits. In addition, the COD content of the wastewater $\left(302 \mathrm{mg} \mathrm{l}^{-1}\right)$ was found to be more than two times the authorized limit, indicating the presence of some organic compounds which were added to the electroplating bath as brighteners, levelers or wetting agents.

It appears from the results shown in Fig. 6 that the residual concentrations of chromium decreased more slowly and reached $2 \mathrm{mg} \mathrm{l}^{-1}$ after an electrolysis time of $20 \mathrm{~min}$. The removal rates of metal ions seems to be relatively slow compared to the removal from synthetic wastewater. This, probably, resulted from the presence of organic compounds which may competitively adsorb on $\mathrm{Al}(\mathrm{OH})_{3}$ coagulant, leading to a substantial reduction of metal ions removal.

The measured COD decreased from $302 \mathrm{mg}$ $\mathrm{l}^{-1}$ to less than $110 \mathrm{mg} \mathrm{l}^{-1}$ after $25 \mathrm{~min}$., which corresponds to a removal efficiency of about $64 \%$. Beyond that time, the residual COD reached a plateau and remained nearly constant. The electrode and volumetric electricity consumptions needed to achieve an effective treatment of the studied industrial wastewater were found to be $1 \mathrm{~g}$ $\mathrm{l}^{-1}$ and $32 \mathrm{~A} \mathrm{~h} \mathrm{l}^{-1}$, respectively. All these results give an indisputable evidence that electrocoagulation can effectively reduce metal ions to a very low level. Dissolved organic compounds present in electroplating 
unit wastewater are also removed. Consequently, electrocoagulation could be an efficient method for heavy metal removal from industrial wastewater.

In conclusion, the results of this study have shown the applicability of electrocoagulation in the treatment of electroplating wastewater containing chromium. The most effective removal capacity was achieved in the $\mathrm{pH}$ range between 4 and 8 . The treatment rate was shown to increase upon increasing the current density. Whereas, $20 \mathrm{~min}$. were needed to achieve an equivalent removal of $\mathrm{Cr}(\mathrm{VI})$. The slower removal of chromium attributed to a difference in the removal mechanisms. Moreover, the charge loading required to achieve an effective treatment, increased with initial concentration. In comparison to chemical coagulation, where several hours are needed and adsorption on activated carbon [Dharnaik and Ghosh, 2014], the electrocoagulation method achieves faster removal of pollutants.

\section{References}

Fu, F., Wang, Q. 2011. Removal of heavy metal ions from wastewaters: A review, J. Environ. Manage., 92: 407.

Jin, W., Zheng, S., Du, H., Xu, H., Zhang, Y. 2010. Isopiestic study of $\mathrm{Na} 2 \mathrm{CrO} 4-\mathrm{H} 2 \mathrm{O}$ system at $353.15 \mathrm{~K}$ : Prediction of the solubility of $\mathrm{Na} 2 \mathrm{CrO} 4$ in aqueous $\mathrm{NaOH}$ solutions, Ind. Eng. Chem. Res., 49: 8244.

Zhitkovich, A. 2011. Chromium in drinking water: Sources, metabolism, and cancer risks, Chem. Res. Toxicol., 24: 1617.

Cao, H., Jin, W. 2015. Industrial Cr(VI) pollution analysis and control strategies in China, The 5th
International Symposium on Metallomics, Guangxi, China, 2015.

Jin, W., Moats, M.S., Zheng, S., Du, H., Zhang, Y., Miller, J.D. 2011. Modulated $\mathrm{Cr}(\mathrm{III})$ oxidation in $\mathrm{KOH}$ solutions at a gold electrode: Competition between disproportionation and stepwise electron transfer, Electrochim. Acta, 56: 8311.

Pereira, C.D., Techy, J.G., Ganzarolli, E.M., Quinaia, S.P. 2012. Chromium fractionation and speciation in natural waters, J. Environ. Monit., 14: 1559 .

Wei, L.L., German, R., Lee, J.M. 2015. Highly efficient reduction of hexavalent chromium on aminofunctionalized palladium nanowires, Appl. Catal. B. Environ., 176-177.

Malaviya, P., Singh, A. 2011. Physicochemical technologies for remediation of chromium-containing waters and wastewaters, Crit. Rev. Sci. Technol., 41: 1111.

Miretzky, P., Cirelli, A.F. 2010. Cr(VI) and $\mathrm{Cr}(\mathrm{III})$ removal from aqueous solution by raw and modified lignocellulosic materials: a review, $J$. Hazard. Mater., 180: 1.

Jin, W., Tolba, R., Wen, J., Li, K., Chen, A. 2013. Efficient extraction of lignin from black liquor via a novel membrane-assisted electrochemical approach, Electrochim. Acta, 107: 611.

Ioannou, L.A., Puma, G.L., Fatta-Kassinos, D. 2015. Treatment of winery wastewater by physicochemical, biological and advanced processes: A review, J. Hazard. Mater., 286: 343.

Hasin, A.A., Gurman, S.J., Murphy, L.M., Perry, A., Smith, T.J., Gardiner, P.H.E. 2010. Remediation of chromium(VI) by a methane- 
oxidizing bacterium, Environ. Sci. Technol., 44: 400.

Jin, W., Wu, G., Chen, A. 2014. Sensitive and Selective Electrochemical detection of chromium(VI) based on gold nanoparticle-decorated titania nanotube arrays, Analyst, 139: 235.

Jin, W., Moats, M.S., Zheng, S., Du, H., Zhang, Y., Miller, J.D. 2012. Indirect electrochemical $\mathrm{Cr}$ (III) oxidation in $\mathrm{KOH}$ solutions at an $\mathrm{Au}$ electrode: the role of oxygen reduction reaction, J. Phys. Chem. B., 116: 7531.

Arar, O., Yiksel, U., Kabay, N., Yuksel, M. 2013. Demineralization of geothermal water reverse osmosis (RO) permeate by electrodeionization (EDI) with layered bed configuration, Desalination, 317: 48.

Dubrawski, K.L., Du, C., Mohseni, M. 2014. General potential-current model and validation for electrocoagulation, Electrochim. Acta, 129: 187.

Meas, Y., Ramirez, J.A., Villalon, M.A., Chapman, T.W. 2010. Industrial wastewaters treated by electrocoagulation, Electrochim. Acta, 55: 8165.

Rodrigo, M.A., Canizares, P., Buitron, C., Saez, C. Electrochemical technologies for the regeneration of urban wastewaters, Electrochim. Acta, 55: 8160.

19) Khandegar, V., Saroha, A.K. 2013. Electrocoagulation for the treatment of textile industry effluent A review, J. Enviorn. Manage., 128: 949.

Barrera-Diaz, C., Lugo-Lugo, V., RoaMorales, G., Natividad, R., MartinezDelgadillo, S.A. 2011. Enhancing the electrochemical $\mathrm{Cr}(\mathrm{VI})$ reduction in aqueous solution, J. Hazard. Mater., 185: 1362.
Jin, W., Zhang, Z., Wu, G., Tolba, R., Chen, A. 2014. Integrated lignin-mediated adsorption-release process and electrochemical reduction for the removal of trace $\mathrm{Cr}(\mathrm{VI}), R S C A d v$. 4: 27843.

Jin, W., Yan, K. 2015. Recent advances in electrochemical detection of toxic Cr(VI), RSC Adv., 5: 37440.

Tian, L.Y., Huang, X., Wu Zhou, C. Electroreduction of hexavalent chromium using a polypyrrolemodified electrode under potentiostatic and potentiodynamic conditions, J. Hazard. Mater., 225226.

Yang, Y., Diao, M.H., Gao, M.M., Sun, X.F., Liu, X.W., Zhang, G.H., Qi, Z., Wang, S.G. 2014. The resistance to over-oxidation for polyaniline initiated by the resulting quinonelike molecules, Electrochim. Acta, 132: 496.

He, Z., Angenent, L.T. 2006. Application of Bacterial Biocathodes in Microbial Fuel Cells, Electroanalysis, 18: 2009.

Huang, L., Chai, X., Cheng, S., Chen, G. 2011. Effect of set potential on hexavalent chromium reduction and electricity generation from biocathode microbial fuel cells, Chem. Eng. J., 166: 652.

Liu, L., Yuan, Y., Li, F., Feng, C. 2011. Insitu $\mathrm{Cr}(\mathrm{VI})$ reduction with electrogenerated hydrogen peroxide driven by iron-reducing bacteria, Bioresour. Technol., 102: 2468.

McCarty, P.L., Bae, J., Kim, J. 2011. Domestic wastewater treatment as a net energy producer-can this be achieved, Environ. Sci. Technol., 45: 7100

An, L., Zhao, T.S. 2011. An alkaline direct ethanol fuel cell with a cation exchange membrane, Energy 
Environ. Sci., 4: 2213.

Zhang, H., Xu, W., Wu, Z., Zhou, M., Jin, T. 2013. Removal of $\mathrm{Cr}(\mathrm{VI})$ with cogeneration of electricity by an alkaline fuel cell reactor, J. Phys. Chem. C, 117: 14479.

Alvarado, L., Chen, A. 2014. Electrode ionization: Principles Strategies and
Applications, Electrochim. Acta, 132: 583.

Dharnaik, A.S., Ghosh, P.K. 2014. Hexavalent chromium $\mathrm{Cr}(\mathrm{VI})$ ) removal by the electrochemical ionexchange process, Environ. Technol., 35: 2272 .

\section{How to cite this article:}

Maryam Sarkhosh, Zahra atafar, Ehsan Ahmadi, shahram nazari, Yadolah Fakhri, soheila rezaei, Seyed Mohsen Mohseni, Mohammad Hossien Saghi and Bahare Baziar. Treatment of Electroplating $\mathrm{Cr}(\mathrm{VI})$ for Reduction $\mathrm{Cr}(\mathrm{VI})$ by Electrocoagulation in Continuous Operation. Int.J.Curr.Microbiol.App.Sci. 5(4): 615-625. doi: http://dx.doi.org/10.20546/ijcmas.2016.504.070 